\title{
MICHAEL ROBERTS
}

We regret to record the death, which occurred on 13th December, 1948, at the early age of 46, of Michael Roberts, one of the founder members of our Society. Roberts served from the beginning on the Provisional Committee which prepared the way for the formal foundation of the Society and his active co-operation and help were much appreciated.

Roberts was educated at King's College, London, and Trinity College, Cambridge, taking a degree in mathematics. He was a science master for many years at the Royal Grammar School, Newcastle-upon-Tyne. During the recent war, he served with the European Services of the B.B.C. In 1945 he became Principal of the College of St. Mark and St. John, Chelsea.

Roberts was a man of remarkably diverse intellectual interests and of high seriousness of mind. This is reflected in his many articles, reviews of books and publications. His books included New Signatures, as anthology of newly published verse (1932), Critique of Poetry and Newton and the Origin of Colours (1934), The Modern Mind (1937), T. E. Hulme, a critical analysis of Hulme's anti-humanist ideas and an extension of them (1938), Recovery of the West (1941).

The Society valued the help which Roberts was able to give, and his counsel and advice at the meetings leading up to its inauguration did much to further the interests of the Society. It was a disappointment to many that Roberts was unable to accept office or even to become a member of the Council. His loss is a great one, and he will be sadly missed by his many friends. He leaves a widow, Miss Janet Adam Smith, a writer of distinction, and four children.

\section{Book Reviews}

The Philosophical Magazine: Natural Philosophy through the Eighteenth Century and Allied Topics. (Commemoration Number to mark the 150th Anniversary of the foundation of the Magazine, Taylor \& Francis, Ltd., 18, Red Lion Court, London, E.C.4. 1948). 15s. pp. viii. + 164 .

The Philosophical Magazine holds a unique position among scientific journals in that it is privately owned, and is not the organ of any institution or scientific body. In this Commemoration Number an account is given by John Ferguson and Allan Ferguson, the Editor, of the foundation of the journal in 1798, and of its subsequent history. This is followed by a series of articles by recognised authorities on the development during the eighteenth century of the sciences of Astronomy, Physics, Chemistry, Mathematics, and Engineering. There are four other articles, by R. S. Whipple on 'Scientific Instruments in the Eighteenth Century', by Douglas McKie on' The Scientific Periodical from 1665 to 1798 ' and on 'Scientific Societies to the end of the Eighteenth Century', and by F. Sherwood Taylor on "The Teaching of the Physical Sciences at the end of the Eighteenth Century'. A number of these articles also include useful bibliographies, and the volume as a whole will be warmly welcomed by all interested in the history of science.

L. J. M. C.

Isis. Vol. 40, Part 4, No. 122 (November, 1949).

George Sarton : Third Preface to Volume Forty : Qualification of Teachers of the History of Science.

Wyndham Miles: Notes on Some Early Chemistry Books published in Pennsylvania.

Iago Galdston : Sigmund Freud : A Critical Summary and Review.

Louise D. Patterson: Hooke's Gravitation Theory and its Influence on Newton. I. Hooke's Gravitation Theory.

Marcel Françon : Le Langage mathématique de J.-J. Rousseau.

Boleslaw Szczesniak : Notes on Kepler's "Tabulae Rudolphinae" in the Library of Pei-t'and in Pekin.

Lynn Thorndike : Concerning John Canonicus.

Notes and Correspondence. Personalia. Obituaries.

Seventy-fourth Critical Bibliography of the History and Philosophy of Science and of the History of Civilization.

\section{Editorship of the Bulletin}

Dr. S. Lilley, after so successfully launching the Bulletin, has unfortunately been compelled by pressure of work to give up the Editorship. The material for the present number was collected by him, but seen through the press by his successor (Dr. N. H. de V. Heathcote).

\section{Notices}

The Sixth International Congress for the History of Science is to be held in Amsterdam from 14th to 20th August, 1950. Full particulars may be obtained from the Secretary, Prof. Ir. R. J. Forbes, Haringvlietstraat 1, Amsterdam. 